Research article

\title{
RELATIONSHIP BETWEEN THE INDEXES OF INSULIN RESISTANCE AND METABOLIC STATUS IN DAIRY COWS DURING EARLY LACTATION
}

\author{
CINCOVIĆ Marko ${ }^{1 *}$, KIROVSKI Danijela ${ }^{2}$, VUJANAC Ivan ${ }^{2}$, BELIĆ Branislava ${ }^{1}$, \\ DJOKOVIĆ Radojica ${ }^{3}$
}

${ }^{1}$ Faculty of Agriculture, Department of Veterinary Medicine, University of Novi Sad, Trg D.Obradovića 8, 21000 Novi Sad, Serbia; ${ }^{2}$ Faculty of Veterinary Medicine, University of Belgrade, Bulevar Oslobođenja 18, 11000 Beograd; ${ }^{3}$ Faculty of Agronomy, Department of Animal Science, University of Kragujevac, Ul.Cara Dušana 34, 32000 Čačak, Serbia

(Received 15 February, Accepted 26 September 2016)

Insulin resistance is a phenomenon which accompanies the ongoing metabolic adaptation in cows during early lactation. The aim of our study was to determine the linear correlations of HOMA (Homeostatic Model Assessment), QUICKI (Quantitative Insulin Sensitivity Check Index) and RQUICKI (Revised Quantitative Insulin Sensitivity Check Index) indexes of insulin resistance with the metabolic status of cows (concentration of hormones, metabolites and body condition score). The experiment included 40 Holstein-Frisian cows in the first week after calving. Indexes of insulin resistance valued: 18.68 \pm 5.43 (HOMA), $0.39 \pm 0.06$ (QUICKI) and $0.45 \pm 0.06$ (RQUICKI). Linear correlations were examined by testing the coefficient of correlation $(\mathrm{r})$, determination $\left(\mathrm{r}^{2}, \%\right)$ and regression parameter beta $(\mathrm{b})$ in linear equation. A negative correlation was found between HOMA and IGF-I (insulin growth factor I) ( $\mathrm{r}=-0.51$, $\left.\mathrm{r}^{2}=25.0, \mathrm{~b}=-1.1257, \mathrm{p}<0.01\right)$. HOMA showed a positive correlation with BHB (betahidroxybutyrate) $\left(\mathrm{r}=0.48, \mathrm{r}^{2}=23.2, \mathrm{~b}=0.0234, \mathrm{p}<0.01\right)$. A positive correlation was found between QUICKI and IGF-I $\left(\mathrm{r}=0.30, \mathrm{r}^{2}=10.0 \mathrm{~b}=46.7900, \mathrm{p}<0.05\right)$ and cholesterol $\left(\mathrm{r}=0.44, \mathrm{r}^{2}=18.3, \mathrm{~b}=1.9021, \mathrm{p}<0.01\right)$. In contrast, QUICKI and $\mathrm{BHB}\left(\mathrm{r}=0.51, \mathrm{r}^{2}=27.1\right.$, $\mathrm{b}=-1.7241, \mathrm{p}<0.01)$, just like QUICKI and BCS $\left(\mathrm{r}=0.46, \mathrm{r}^{2}=20.9, \mathrm{~b}=-2.424, \mathrm{p}<0.01\right)$, showed a negative correlation. RQUICKI showed positive correlations with IGF-I $\left(\mathrm{r}=0.48, \mathrm{r}^{2}=22.8, \mathrm{~b}=28.1230, \mathrm{p}<0.01\right), \mathrm{T} 4\left(\mathrm{r}=0.47, \mathrm{r}^{2}=22.1, \mathrm{~b}=87.142, \mathrm{p}<0.01\right)$ and triglycerides $\left(\mathrm{r}=0.36, \mathrm{r}^{2}=13, \mathrm{~b}=0.0407, \mathrm{p}<0.05\right)$ but negative correlations with cortisol $\left(\mathrm{r}=-0.36, \mathrm{r}^{2}=13.0, \mathrm{~b}=-9.0332, \mathrm{p}<0.05\right), \mathrm{STH}$ (somatotropic hormone) $\left(\mathrm{r}=-0.42, \mathrm{r}^{2}=17.3\right.$, $\mathrm{b}=-5.4976, \mathrm{p}<0.01)$, BHB $\left(\mathrm{r}=-0.62, \mathrm{r}^{2}=38.3, \mathrm{~b}=-1.1872, \mathrm{p}<0.01\right)$, total bilirubin $(\mathrm{r}=-$ $\left.0.58, \mathrm{r}^{2}=33.7, \mathrm{~b}=-7.131, \mathrm{p}<0.01\right)$ and BCS (body condition score) $\left(\mathrm{r}=-0.6, \mathrm{r}^{2}=36.4, \mathrm{~b}=-\right.$ $1.8347, \mathrm{p}<0.01)$. In conclusion, indexes of insulin resistance may be used to evaluate the metabolic status of cows in early lactation. RQUICKI might be the most appropriate predictor of metabolic status due to its linear relationship with most of the parameters included in homeorhetic process.

Key words: cows, insulin resistance, metabolic status, early lactation

\footnotetext{
*Corresponding author: e-mail: mcincovic@gmail.com
} 


\section{INTRODUCTION}

Insulin resistance is a phenomenon that occurs in early lactation and is characterised by lower insulin production and lower tissue response to insulin. It allows two important processes: conservation of glucose for lactose production in milk and increased lipolysis followed by increased NEFA (non-esterified fatty acids) concentration for energy purpose $[1,2]$. These changes are related to milk production initiation, reduced feed intake, negative energy balance, as well as endocrine and metabolic changes at calving [3].

Insulin resistance can be determined by numerous methods, such as direct, indirect and surrogate methods. Surrogate methods are indexes calculated from the basal concentration of insulin, glucose and/or NEFA, and include the following indexes: 1/insulin, insulin:glucose ratio, HOMA (Homeostatic Model Assessment), QUICKI (Quantitative Insulin Sensitivity Check Index) and RQUICKI (Revised Quantitative Insulin Sensitivity Check Index) [4]. Indexes of insulin resistance relevance have been estimated by comparison with results obtained by hyperinsulinemic euglicemic clamp as the golden method for determination of insulin resistance [5].

It is known that some metabolic adaptations that characterize the early lactation period, are in relation with insulin resistance. These adaptations are increased lipid mobilization, ketogenesis and lipid oxidation [6-8], reduced levels of thyroid hormones [9], changed STH to IGF-I ratio [10], increased levels of cortisol [11], changes in hepatic insulin receptors abundance, increased activity of hepatic enzymes $[6,12,13]$ and reduced concentration of $\mathrm{Ca}$ and $\mathrm{P}[14,15]$. However, there is a lack of literature data related to the direct relationship between the value of the indexes of insulin resistance and metabolic or endocrine parameters. The aim of this study was to examine the relations between HOMA, QUICKI and RQUICKI indexes of insulin resistance with parameters of metabolic status (concentrations of hormones, metabolites and body condition score) in cows during early lactation.

\section{MATERIALS AND METHODS}

\section{Animals}

The experiment included 40 Holstein-Frisian cows in the second and third lactation. No signs of health disorder were found in previous lactations in these animals. Average milk production of selected cows was $7000 \mathrm{l}$. Cows were raised in free system, on deep litter, and spent the transition period ( 3 weeks before to 3 weeks after calving) in rooms for calving where the tie stall system was applied. Cows were fed at $7 \mathrm{~h}, 14 \mathrm{~h}$ and 20h. Total mixed rations (TMR) were given and all needs were met. Water was taken ad libitum. Drinkers were automatic and allowed fresh water consumption. Corn silage (20-25 kg), alfalfa hay ( $5 \mathrm{~kg}$ ), beet pulp (3-5 kg), concentrate part (5-7 kg) and other additions were included in the diet. Following standards were applied: proteins 
(17.5-19.5\% SM crude proteins, 30-33\% degradable proteins per total, 35-40\% nondegradable proteins per total protein percentage). Carbohydrates (ADF minimum 17$21 \%$, NDF minimum 28-31\%, NDF from forages minimum 18-23\%, non-structure carbohydrates $35-42 \%$, dry matter level from forages minimum 40-45\%) were included in the meal. In addition, $5 \%$ fat and energy (NEL 7-7.4 MJ $/ \mathrm{kg}$ dry matter of the meal) were contained in each meal.

\section{Sampling}

Blood samples were taken in the first week, and 3-7 days after calving. V. jugularis was punctured in the 11-14h period to avoid prandial effects on metabolism. Blood samples were stored in a refrigerator in heparin vacutainers and refrigerated pending analysis. The time period from blood sampling to blood processing in the laboratory was $3 \mathrm{~h}$. Blood processing included centrifugation at 1,000 $\mathrm{g}$ for 20 minutes. Thereafter, the plasma was decanted and stored at $-20^{\circ} \mathrm{C}$ until analyzed. Concentrations of hormones and metabolic profile parameters were determined in all plasma samples.

\section{Parameters of metabolical status determination}

Concentration of hormones, metabolic parameters and body condition were determined in order to estimate the metabolic status.

Glucose and NEFA concentrations were determined by colorimetry using commercial kits of (Randox-UK). ELISA method (kit Cusabio, Ch and Endocrine Technologies Inc. CA, USA) was used to determine insulin concentrations. Values were read on ELISA reader Rayto.

IGF-I (Cusabio, Ch), cortisol (Uscn-Life Science, China), STH (Endocrine technologies, US), T3 (Endocrine technologies, US), T4 (Endocrine technologies, US) concentrations were determined by ELISA, measurements done at $450 \pm 2 \mathrm{~nm}$.

$\mathrm{BHB}$, total bilirubin, total protein, albumin, urea, cholesterol, triglycerides, AST, ALT, $\mathrm{Ca}, \mathrm{P}$ and MDA metabolic parameters were determined using spectrophotometry. Standard kits, from Randox (UK) and Pointe scientific (US) were used. Parameters of the metabolic profile in the blood samples were determined by means of photometric reactions. (Photometer Rayto RT1904c).

Body condition was determined at the moment of blood sampling. Evaluation of body condition was carried out by giving marks 1-5. Minimal ratio between two marks was 0.25. Recommendations from guide Elanco Animal Health Buletin Al 8478 (Rev.9/96) were considered.

\section{Indexes of insulin resistance determination}

HOMA, QUICKI and RQUICKI insulin indexes values were determined. The following formulas were used to determine these indexes: HOMA $=$ glucose $(\mathrm{mmol} / \mathrm{l}) \mathrm{x}$ 
insulin $(\mu \mathrm{U} / \mathrm{mL})$; QUICKI $=1 /[\log ($ glucose $\mathrm{mg} / \mathrm{dL})+\log ($ insulin $\mu \mathrm{U} / \mathrm{mL})]$ and RQUICKI $=1 /[\log ($ glucose $\mathrm{mg} / \mathrm{dL})+\log ($ insulin $\mu \mathrm{U} / \mathrm{mL})+\log (\mathrm{NEFA} \mathrm{mmol} / \mathrm{l})]$.

\section{Statistical analysis}

Relationship between indexes of insulin resistance, concentrations of hormones that are parameters of metabolic status and body condition were determined by coefficient correlation analysis ( $r$, Pierson's coefficient of correlation). Determination $\left(\mathrm{r}^{2}\right.$, represented in percentage of the common variation) was used as well. Regression analysis with determination of parameter beta (b) was performed when linear relation was proved (value of indexes of resistance was independent variable but concentrations of hormones and body condition were the dependent variable). Statgraphic Centurion (Statepoint Technologies Inc.Warrenton, Va, Virginia, USA) statistical program was used.

\section{RESULTS}

Mean concentrations of insulin, glucose, NEFA and values of HOMA, QUICKI and RQUICKI are shown in Table 1.

Table 1. Concentrations of insulin, glucose and NEFA and value of HOMA, QUICKI and RQUICKI indexes in examined cows

\begin{tabular}{lccccc}
\hline & Mean & SD & CV (\%) & min & max \\
\hline Insulin $\mu \mathrm{U} / \mathrm{ml}$ & 5.91 & 1.73 & 28.8 & 3.7 & 8.8 \\
Glucose $\mathrm{mmol} / \mathrm{l}$ & 3.16 & 0.84 & 26.6 & 2.12 & 4.17 \\
NEFA mmol/1 & 0.51 & 0.12 & 23.52 & 0.28 & 0.69 \\
HOMA & 18.68 & 5.43 & 29.1 & 12.3 & 25.2 \\
QUICKI & 0.39 & 0.06 & 15.4 & 0.29 & 0.48 \\
RQUICKI & 0.45 & 0.06 & 12.6 & 0.35 & 0.77 \\
\hline
\end{tabular}

Correlations between indexes of insulin resistance, parameters of metabolic profile and body condition were determined by testing the coefficient of correlation. Analysis of coefficient determination was also applied (Table 2). HOMA index showed significant linear correlations with parameters of endocrine and metabolic status: HOMA:IGF-I $(\mathrm{r}=0,51 ; \mathrm{p}<0,01)$ and HOMA:BHB $(\mathrm{r}=0,48 ; \mathrm{p}<0,01)$. A linear correlation with other parameters was not proved. QUICKI showed the following significant relations: QUICKI:IGF-I ( $\mathrm{r}=-0,3 ; \mathrm{p}<0,05) ;$ QUICKI:BHB ( $\mathrm{r}=0,51 ; \mathrm{p}<0,01) ;$ QUICKI: cholesterol $(\mathrm{r}=0,44 ; \mathrm{p}<0,01)$; QUICKI: body condition $(\mathrm{r}=-0,46 ; \mathrm{p}<0,01)$. In addition to that, RQUICKI showed linear correlation with following parameters: RQUICKI:IGF-I $(\mathrm{r}=0,48 ; \mathrm{p}<0,01)$, RQUICKI:cortisol ( $\mathrm{r}=-0,36 ; \mathrm{p}<0,05)$, RQUICKI:STH ( $\mathrm{r}=-0,42$; $\mathrm{p}<0,01)$, RQUICKI:T4 ( $\mathrm{r}=0,47 ; \mathrm{p}<0,01)$, RQUICKI:triglycerides $(\mathrm{r}=0,36 ; \mathrm{p}<0,05)$. 
RQUICKI:BHB ( $\mathrm{r}=-0.62 ; \mathrm{p}<0.01)$, RQUICKI:bilirubin $(\mathrm{r}=-0.58 ; \mathrm{p}<0.01)$ and RQUICKI: body condition score $(\mathrm{r}=-0.6 ; \mathrm{p}<0.01)$.

Coefficient of determination is relevant in determining the strength of association between insulin resistance indexes and endocrine and metabolic profile. Body condition needs to be included, too. Coefficient of determination, in fact, represents the percentage variability of two parameters. Percentage variability of IGF-I that can be explained by HOMA, was $25.21 \%$, QUICKI was $10 \%$ and RQUICKI $22.8 \%$. Percentage variability of $\mathrm{BHB}$ that can be explained by varying insulin resistance indexes was 23.2\% (HOMA), 27.1\% (QUICKI) and 38.3\% (RQUICKI). Percentage variability of body condition that can be explained by varying insulin resistance indexes was $20.91 \%$ (QUICKI), 36.4\% (RQUICKI). Percentage variability of cholesterol that can be explained by varying QUICKI index was $18.3 \%$. Percentage variability of other parameters that can be explained by varying RQUICKI index was $13 \%$ for cortisol, $17.3 \%$ for STH, $22.1 \%$ for T4, 13\% for triglycerides and $33.7 \%$ for total bilirubin.

Table 2. Coefficient of correlation ( $\mathrm{r}$ ) and determination $\left(\mathrm{r}^{2}, \%\right)$ between indexes of insuln resistance and concentrations of hormones, metabolites and body condition in cows

\begin{tabular}{|c|c|c|c|c|c|c|}
\hline & \multicolumn{2}{|c|}{ HOMA } & \multicolumn{2}{|c|}{ QUICKI } & \multicolumn{2}{|c|}{ RQUICKI } \\
\hline & $\mathbf{r}$ & $r^{2}(\%)$ & $\mathbf{r}$ & $r^{2}(\%)$ & $\mathbf{r}$ & $\mathbf{r}^{2}(\%)$ \\
\hline IGF-I & $-0.51 * *$ & 25.21 & $0.3^{*}$ & 10 & $0.48^{* *}$ & 22.8 \\
\hline Cortisol & $0.15^{N S}$ & 2.25 & $-0.19^{N S}$ & 3.61 & $-0.36 *$ & 13 \\
\hline STH & $0.08^{N S}$ & 0.64 & $-0.11^{N S}$ & 1.21 & $-0.42 * *$ & 17.3 \\
\hline $\mathrm{T} 3$ & $-0.14^{N S}$ & 1.96 & $0.11^{N S}$ & 1.21 & $0.18^{N S}$ & 3.24 \\
\hline $\mathrm{T} 4$ & $-0.11^{N S}$ & 1.21 & $0.16^{N S}$ & 2.56 & $0.47 * *$ & 22.1 \\
\hline $\mathrm{BHB}$ & $0.48^{* *}$ & 23.2 & $-0.51 * *$ & 27.1 & $-0.62 * *$ & 38.3 \\
\hline Total protein & $0.14^{N S}$ & 1.96 & $-0.12^{N S}$ & 1.44 & $-0.09^{N S}$ & 0.81 \\
\hline Albumin & $0.04^{N S}$ & 0.16 & $-0.09^{N S}$ & 0.81 & $-0.07^{N S}$ & 0.49 \\
\hline Urea & $0.17^{N S}$ & 2.89 & $-0.12^{N S}$ & 1.44 & $-0.19^{N S}$ & 3.61 \\
\hline Cholesterol & $0.12^{N S}$ & 1.44 & $0.44 * *$ & 18.3 & $-0.18^{N S}$ & 3.24 \\
\hline Triglycerides & $0.14^{N S}$ & 1.96 & $0.11^{N S}$ & 1.21 & $0.36 *$ & 13 \\
\hline Total bilirubin & $0.16^{N S}$ & 2.56 & $-0.2^{N S}$ & 4 & $-0.58 * *$ & 33.7 \\
\hline AST & $0.04^{N S}$ & 0.16 & $0.14^{N S}$ & 1.96 & $-0.19^{N S}$ & 3.61 \\
\hline ALT & $0.13^{N S}$ & 1.69 & $0.04^{N S}$ & 0.16 & $-0.16^{N S}$ & 2.56 \\
\hline $\mathrm{Ca}$ & $0.14^{N S}$ & 1.96 & $-0.09^{N S}$ & 0.81 & $-0.14^{N S}$ & 1.96 \\
\hline $\mathrm{P}$ & $-0.07^{N S}$ & 0.49 & $0.08^{N S}$ & 0.64 & $0.14^{N S}$ & 1.96 \\
\hline MDA & $0.04^{N S}$ & 0.16 & $-0.13^{N S}$ & 1.69 & $-0.15^{N S}$ & 2.25 \\
\hline Body condition & $0.2^{\mathrm{NS}}$ & 4 & $-0.46 * *$ & 20.91 & $-0.6 * *$ & 36.4 \\
\hline
\end{tabular}

${ }^{*} \mathrm{p}<0.05 ; * * \mathrm{p}<0.01{ }^{\mathrm{NS}}$ nonsignificant 
Regression analysis allows for the determination of the intensity of the changes of metabolic profile parameters into the index of insulin resistance unit change as well as the type of connection (positive or negative correlation). It can be done by analysis of linear equation and parameter beta (b) equation. Parameter b can easily be spotted in graphics, because the linear equation is represented in the form $\mathrm{Y}=\mathrm{bXi}+\mathrm{a}$. As the HOMA value increased (higher degree of insulin resistance) IGF-I concentrations decreased. In contrast, the concentration of $\mathrm{BHB}$ increased (Figure 1). As QUICKI values decreased (higher insulin resistance) BHB concentrations increased, but IGF-I and cholesterol concentrations increased. Higher marks of body condition were noted in these cows (Figure 2). As RQUICKI value decreased (higher

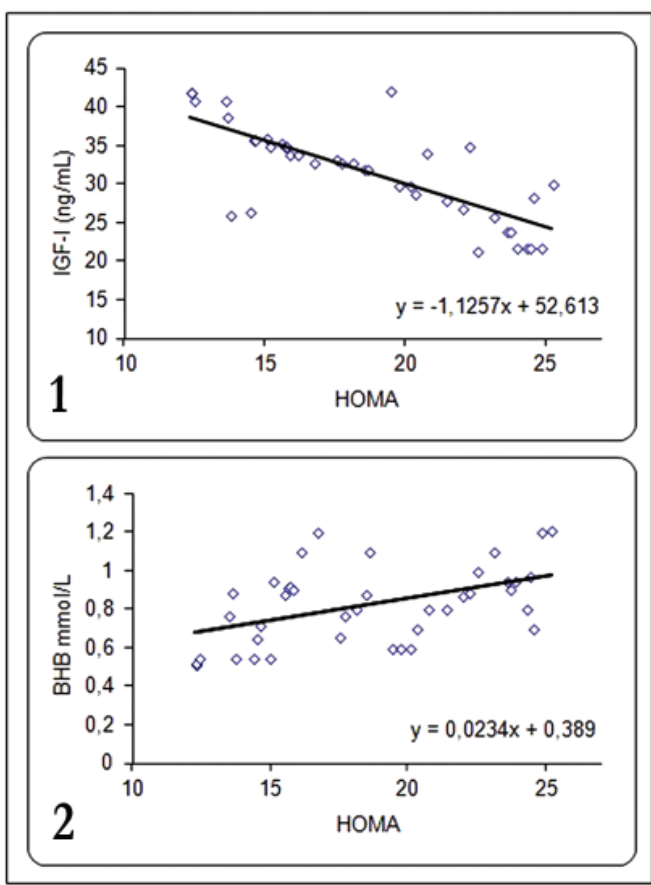

Figure 1. Linear regression between HOMA and concentrations of IGF-I and BHB

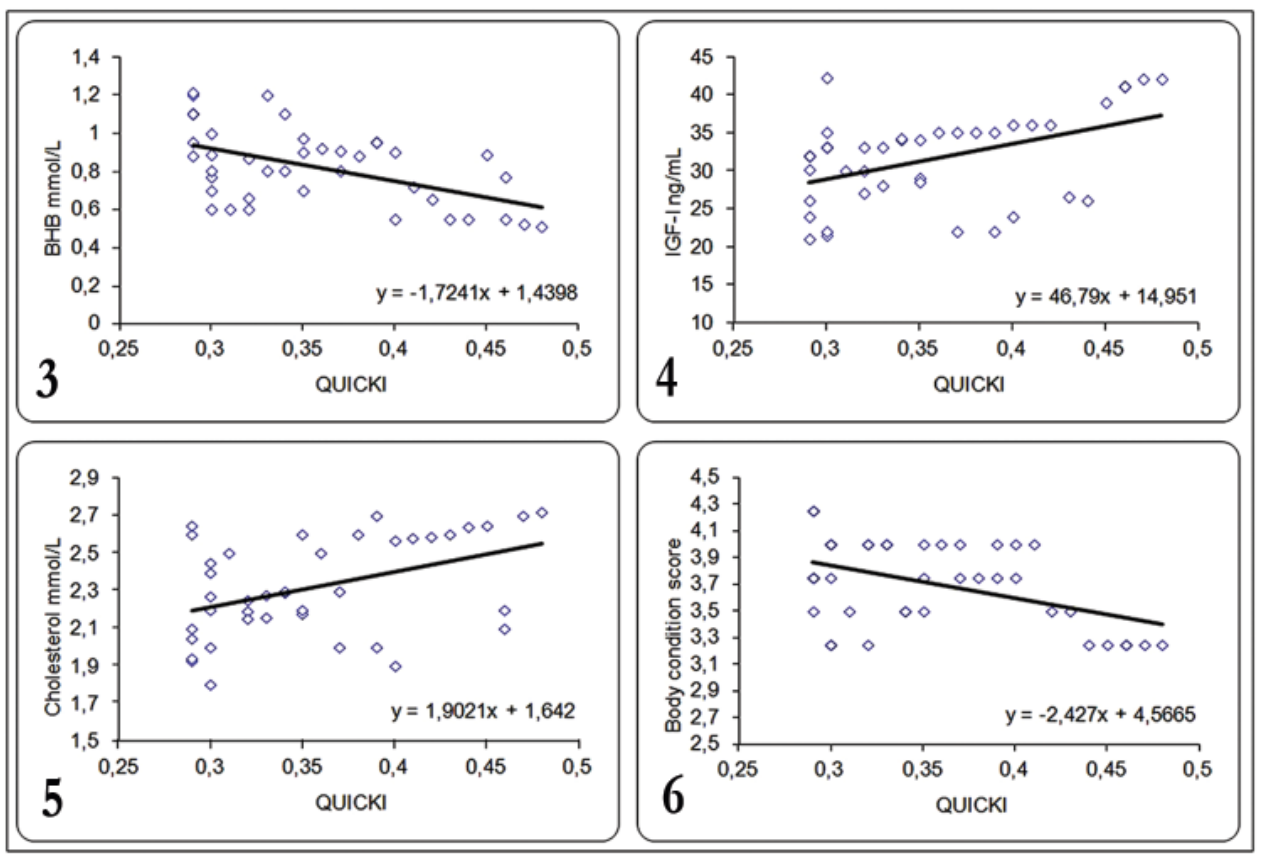

Figure 2. Linear regression between QUICKI index and concentrations of IGF-I, BHB, cholesterol and value of body condition score 
insulin resistance), cortisol, $\mathrm{STH}, \mathrm{BHB}$ and total bilirubin increased and body condition was rated higher. In contrast, concentrations of IGF-I, T4 and triglycerides were lower. Regression analyses with independent variable RQUICKI are given in (Figure 3).

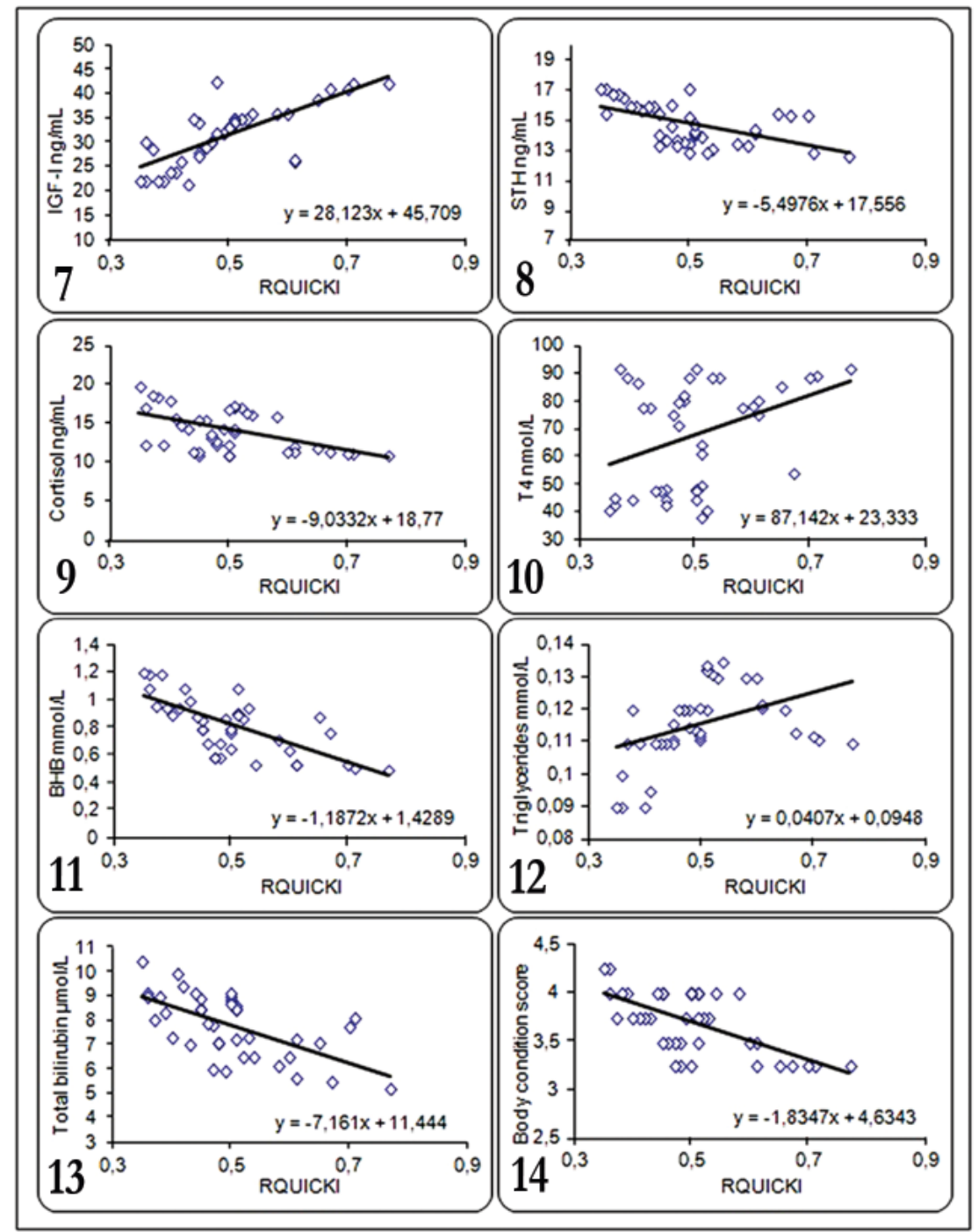

Figure 3. Linear regression between RQUICKI index and concentrations of IGF-I, STH, cortisol, T4, BHB, triglycerides, total bilirubin and value of body condition score

\section{DISCUSSION}

Insulin effects on glucose metabolism in ruminants depend from insulin secretion by the pancreas and insulin sensitivity of the adipose tissue, liver and skeletal muscles 
$[1,3]$. Early lactation is characterized by low insulin production with increased concentrations of NEFA from the adipose tissue. Cows are in a positive energy balance with a higher glucose concentration which accelerated insulin secretion during the dry period, probably because of lower tissue sensitivity to insulin. Regression analysis showed that the value of RQUICKI index is dependant on the insulin value in dry cows, but on NEFA value in early lactation cows [16]. Kirovski (2015) [17] in her review about metabolic and endocrine adaptation of calves to extra-uterine life described that during this period exists hepatic insulin resistance, because calf need extra glucose originating from hepatic gluconeogenesis.

HOMA was valued $18.86 \pm 5.43$. There are scarce reports on the relationship between HOMA values and insulin resistance in cows. Haarstrich (2011) [18] noted a HOMA value of $31.1 \pm 14.9$ in lactating dairy cows, that was higher compared to values in our cows. Cows in the experiment obtained by Haarstrich were in day 182 of lactation, meaning in a later lactation period compared to our cows. Hackbart and coworkers (2013) [11] showed effects of dexamethasone on insulin resistance since HOMA index value was $5.0 \pm 1.0$ before and $15.0 \pm 2.5$ after application of dexamethasone.

Our results showed that HOMA index has a lower reproducibility (higher deviation) in comparison with QUICKI and RQUICKI. Earlier works show the same [19], as QUICKI index value was $0.39 \pm 0.06$, while RQUICKI valued $0.45 \pm 0.06$. Distribution of frequency values of both parameters was inclined to the right side and below average values were dominant. Our results are in agreement with results obtained by Haarstrich (2011) [18]. QUICKI value is a bit higher in calves $0.52 \pm 0.039$ [19]. RQUICKI index measured in the range $0.38-0.65$ [17,21,22,23,24]. Our results are in agreement to the reported range. is also in that range. Reduced insulin sensitivity was shown in the examined population, meaning that insulin resistance is present in the population. There is insufficient data on QUICKI values in dairy cows.

Lower concentrations of IGF-I were found in cows with expressed insulin resistance. HOMA, QUICKI and RQUICKI indexes showed a significant statistic correlation with IGF-I. IGF-I is synthesized in the liver. STH controls this process. It is well known that the concentration of STH is higher in early lactation. However, IGF-I concentration is decreased. A lower level of insulin in this period (insulin resistance) can cause reduced expression of STH receptors $[10,25,26]$. This could be one of the reasons for higher concentrations of STH. Insulin resistance (or lack of insulin) can be directly related to low concentrations of IGF-I. Gross et al. (2011) [24] showed that early lactating cows that were exposed to negative energy balance had a reduced RQUICKI index, meaning that insulin resistance was present in these cows, as well as reduced levels of IGF-I. We found the same positive correlation between RQUICKI and IGF-I. As opposite to our results, Kerestes (2009) [23] found a negative correlation between RQUICKI and IGF-I. Studies in human medicine show that insulin resistance and diabetes type II can be related either to reduced or greater concentrations of IGF-I. Negative correlation was noted between STH and RQUICKI index in our research. This result was expected considering the negative correlation of STH with 
IGF-I. Attention should be on higher concentrations of NEFA into blood stream in early lactation. NEFA are an integral part of the formula for calculating RQUICKI index. Application of STH to heifers cause reduction of RQUICKI levels (greater insulin resistance) due to increase of insulin, glucose and NEFA [27].

Cortisol concentrations showed a significant negative correlation with RQUICKI index. Classification of cows on quartiles did not show significant results because of physiologically high variations of cortisol concentrations. Application of dexamethasone leads to greater insulin resistance [11]. Well known fact is that healthy people that were treated with dexamethasone show insulin resistance. The reason for that is the reduced use of glucose in peripheral tissues. The problem is on the post-receptor level [28] which has been shown on the animal model, too [29]. Also, cortisol is in a positive correlation with MDA, which production is increased by insulin resistance [30,31].

Breneta (2011) [9] indicates on the relation between hypothyroidism and insulin resistance. This could be explained by the fact that thyroid hormones have a direct favorable influence on the expression of genes that code glucose transporters (GLUT) in the tissue. Huszenicza et al., (2002) [32] showed a negative correlation between NEFA and thyroid hormones in cows in early lactation. A negative correlation was found between BHB and thyroid hormones.

$\mathrm{BHB}$, cholesterol, triglycerides, bilirubin, ALT, AST and urea were predicted by indexes of insulin resistance, mostly by RQUICKI. A significant correlation was found between all three indexes of insulin resistance and BHB. A positive correlation was found with HOMA, and negative with QUICKI and RQUICKI. Weber and coworkers, (2013) [33] showed that HOMA values are significantly lower in the group of cows that have a high degree of triacylglycerol accumulation in the liver. Studies on human populations show that fatty liver can develop as a consequence of peripheral insulin resistance. Values of indexes of insulin resistance and lipid profile are significantly different in comparison to healthy persons [34]. Greater concentration of NEFA blocks insulin signaling in hepatocytes when beta oxidation of fatty acids happens [35]. There is a reduced production of VLDL, which is needed for lipid transport from the liver. Changes in transcription and post transcription of proteins that are contained in VLDL affect liver and lead to fat infiltration [36]. Participation of NEFA in the calculation of RQUICKI index links them with cholesterol and triglycerides.

Body condition score of cows showed a significant correlation with the degree of insulin resistance. Cows with greater body condition are more prone to develop insulin resistance. Holtenuis and Holtenuis (2007) [19] are the first users of RQUICKI index. They found a negative correlation of this index and body condition score. This statement is approved in a recent research conducted by Jaakson and coworkers (2013) [37]. The adipose tissue produces many substances that increase insulin resistance [38]. A consequence of this is the negative correlation between RQUICKI index and body condition score. Cows in the prepartum period do not show hepatic insulin 
resistance. Moreover, insulin resistance is specific for adipose tissue when cows lose weight and the body condition score decreases [39]. Loosing weight leads to increased levels of NEFA and decreased values of RQUICKI index. That explains the strong linear correlation that was determined in our study. High-BCS prepartum cows showed insulin resistance and a fatty liver which were in relation with the increased hepatic expression of insulin receptor beta (IR $\beta$ ), fatty acid translocase (FAT/CD36) and sterol regulatory element-binding protein-1 (SREBP-1) [40].

\section{CONCLUSION}

The relationship between indexes of insulin resistance and the tested metabolic parameters showed a linear relationship in dairy cows during early lactation. RQUICKI index, compared to HOMA and QUICKI indexes, is the better predictor of metabolic status in early lactating cows due to its linear relation to many parameters included in homeorhetic process during early lactation.

\section{Acknowledgement}

This research is part of project TR31062 supported by Ministry of education, science and technological development, Serbia.

\section{Authors' contributions}

CM carried out laboratory analysis, participated in the design, performed statistical analysis of study and drafted the manuscript. KD conceived of the study, and participated in its design and coordination and helped to draft the manuscript. VI participated in design of study and helped to draft the manuscript. BB carried out the immunoassays and performed statistical analysis. DjR carried out the immunoassays. All authors read and approved the final manuscript.

\section{Declaration of conflicting interests}

The author(s) declared no potential conflicts of interest with respect to the research, authorship, and/or publication of this article.

\section{REFERENCES}

1. De Koster JD, Opsomer G: Insulin resistance in dairy cows. Vet Clin North Am Food Anim Pract 2013, 29(2):299-322.

2. Sundrum A: Metabolic Disorders in the Transition Period Indicate that the Dairy Cows' Ability to Adapt is Overstressed. Animals 2015, 5: 978-1020. 
3. Hayirli A: The role of exogenous insulin in the complex of hepatic lipidosis and ketosis associated with insulin resistance phenomenon in postpartum dairy cattle. Vet. Res. Commun. 2006, 30:749-774.

4. Singh B, Saxena A: Surrogate markers of insulin resistance: A review. World J Diabetes 2010, 1(2):36-47.

5. Lee S, Muniyappa R, Yan X, Chen H, Yue LQ, Hong EG, Kim JK, Quon MJ: Comparison between surrogate indexes of insulin sensitivity and resistance and hyperinsulinemic euglycemic clamp estimates in mice. Am J Physiol Endocrinol Metab 2008, 294(2):E261270.

6. Oikawa S, Oetzel GR: Decreased insulin response in dairy cows following a four-day fast to induce hepatic lipidosis. J. Dairy Sci. 2006, 89:2999-3005.

7. Bossaert P, Leroy JL, De Vliegher S, Opsomer G: Interrelation between glucose-induced insulin response, metabolic indicators, and the time of first ovulation in high-yielding dairy cows. J. Dairy Sci 2008, 91:3363-3371.

8. Evans JL, Maddux BA, Goldfine ID: The molecular basis for oxidative stress-induced insulin resistance. Antioxid Redox Signal 2005, 7(7-8):1040-52.

9. Brenta G: Why Can Insulin Resistance Be a Natural Consequence of Thyroid Dysfunction? Journal of Thyroid Research 2011, doi:10.4061/2011/152850.

10. Butler ST, Marr AL, Pelton SH, Radcliff RP, Lucy MC, Butler RW: Insulin restores GH respoonsiveness during lactation-induced negative energy balance in dairy cattle: effects on expression of IGF-I ang GH receptor 1A. J Endocrinol 2003, 176:205-217.

11. Hackbart KS, Cunha PM, Meyer RK, Wiltbank MC: Effect of Glucocorticoid-Induced Insulin Resistance on Follicle Development and Ovulation. Biol reprod 2013, doi:10.1095/ biolreprod.113.107862.

12. Bonnet F, Ducluzeau PH, Gastaldelli A, Laville M, Anderwald CH, Konrad T, Mari A, Balkau B: Liver Enzymes Are Associated With Hepatic Insulin Resistance, Insulin Secretion, and Glucagon Concentration in Healthy Men and Women. Diabetes 2011, 60:1660-1667.

13. Zhang Z, Li X, Liu G, Gao L, Guo C, Kong T, Wang H, Gao R, Wang Z, Zhu X: High Insulin Concentrations Repress Insulin Receptor Gene Expression in Calf Hepatocytes Cultured in Vitro. Cell Physiol Biochem 2011, 27:637-640.

14. Littledike ET, Whipp SC, Witzel DA, Baetz AL: Insulin, corticoids, and parturient paresis. Academic Press, New York, NY, 1970. Cited in: Goof J.P., Horst R.L.: Physiological Changes at Parturition and Their Relationship to Metabolic Disorders. J.Dairy Sci. 1997, 80(7):1260-1268.

15. Zhou XJ, Fadda GZ, Perna AF, Massry SG: Phosphate depletion impairs insulin secretion by pancreatic islets. Kidney International 1991, 39:120-128.

16. Cincović MR, Belić B, Đoković R, Toholj B, Hristovska T, Delić B, Došenović M: Insulin resistance in cow during dry period and early lactation. Contemporary agriculture 2014, 63 (1-2), 98-105.

17. Kirovski D: Endocrine and metabolic adaptations of calves to extra-uterine life. Acta VetBeograd 2015, 65 (3), 297-318.

18. Haarstrich D: Evaluation of surrogate indices of insulin sensitivity by means of hyperinsulinemiceuglycemic glucose clamps in dairy cows; in: Insulinsensitivität und Insulinresponse nach einer Langzeit-Supplementation von konjugierten Linolsäuren bei laktierenden Milchkühen. Inaugural disertation. Tierärztliche Hochschule Hannover, 2011. 
19. Antuna-Puente B, Faraj M, Karelis AD, Garrel D, Prudhomme D, Rabasa-Lhoret R, Bastard JP: HOMA or QUICKI: Is it useful to test the reproducibility of formulas? Diabetes \& Metabolism 2008, 34(3):294-296.

20. Bossaert P, Leroy JLMR, De Campeneere S, De Vliegher S, Opsomer G: Differences in the glucose induced insulin response and the peripheral insulin responsiveness between neonatal calves of the Belgian Blue, Holstein-Friesian, and East Flemish breeds. J Dairy Sci 2009, 92(9):4404-4411.

21. Holtenius P., Holtenius K.: A model to estimate insulin sensitivity in dairy cows. Acta Veterinaria Scandinavica 2007, 49:29-31.

22. Balogh O, Szepes O, Kovacs K, Klucsar M, Reiczigel J, Alcazar JA, Keresztes M, Febel H, Bartyik J, Fekete SG, Fesus L, Huszenicza G: Interrelationship of growth hormone AluI polymorphysm, insulin resistance, milk production and reproductive performance in Holstein-Friesian cows. Veterinarni Medicina 2008, 53(11):604-616.

23. Kerestes M, Faigl V, Kulcsár M, Balogh O, Földi J, Fébel H, Chilliard Y, Huszenicza G.: Periparturient insulin secretion and whole-body insulin responsiveness in dairy cows showing various forms of ketone pattern with or without puerperal metritis. Domest Anim Endocrinol. 2009, 37(4):250-261.

24. Gross J, van Dorland HA, Schwarz FJ, Bruckmaier RM: Endocrine changes and liver mRNA abundance of somatotropic axis and insulin system constituents during negative energy balance at different stages of lactation in dairy cows. J. Dairy Sci 2011, 94:3484 3494.

25. Rhoads RP, Kim JW, Leury BV, Baumguard LH, Segoale N, Frank SJ, Bauman DE, Boisclair YR: Insulin increases the abundance of the growth hormone receptor in liver and adipose tissue of periparturient dairy cows. J. Nutr. 2004, 134:1020-1027.

26. Kim JW, Rhoads RP, Block SS, Overton TR, Frank SJ, Boisclair RY: Dairy cows experience selective reduction of the hepatic growth hormone receptor during the periparturient period. J. Endocrinol 2004, 181:281-290.

27. Aboin AC, Cooke RF, Vieira FVR, Leiva T, Vasconcelos JLM: Effects of bovine somatotropin injection on serum concentrations of progesterone in non-lactating dairy cows. Livestock Science 2013, 154:240-245.

28. Pagano G, Cavallo-Perin P, Cassader M, Bruno A, Ozzello A, Masciola P, Dall'omo AM, Imbimbo B: An in vivo and in vitro study of the mechanism of prednisone-induced insulin resistance in healthy subjects. J Clin Invest 1983, 72(5):1814-1820.

29. Buren J, Liu HX, Jensen J, Eriksson JW: Dexamethasone impairs insulin signalling and glucose transport by depletion of insulin receptor substrate-1, phosphatidylinositol 3-kinase and protein kinase B in primary cultured rat adipocytes. Eur J Endocrinol 2002, 146:419-429.

30. Jovanović IB, Veličković M, Mllanović S, Valčić O, Gvozdić D, Vranješ-Đurić S: Supplemental selenium reduces the levels of biomarkers of oxidative and general stress in peripartum dairy cows. Acta Vet-Beograd 2015, 65 (2), 191-201.

31. Mizuno T, Matsui H, Imamura A, Numaguchi Y, Sakai K, Murohara T, Okumura K: Insulin resistance increases circulating malondialdehyde-modified LDL and impairs endothelial function in healthy young men. Int J Cardiol. 2004, 97(3), 455-61.

32. Huszenicza GY, Kulscar M, Rudas P: Clinical endocrinology of thyroid gland function in ruminants. Vet. Med. Czech 2002, 47(7):199-210.

33. Weber C, Hametner C, Tuchscherer A, Losand B, Kanitz E, Otten W, Singh SP, Bruckmaier RM, Becker F, Kanitz W, Hammon HM: Variation in fat mobilization during early lactation 
differently affects feed intake, body condition, and lipid and glucose metabolism in highyielding dairy cows. J. Dairy Sci. 2013, 96:165-180.

34. Qureshi K, Clements RH, Saeed F, Abrams GA: Comparative Evaluation of Whole Body and Hepatic Insulin Resistance Using Indices from Oral Glucose Tolerance Test in Morbidly Obese Subjects with Nonalcoholic Fatty Liver Disease. Journal of Obesity 2010, Article ID 741521, 7 pages.

35. Nagle CA, Klett EL, Coleman RA: Hepatic triacylglycerol accumulation and insulin resistance. J. Lipid Res. 2009, 50:S74-S79.

36. Bernabucci U, Basiricò L, Pirazzi D, Rueca F, Lacetera N, Lepri E, Nardone A: Liver apolipoprotein B100 expression and secretion are down-regulated early postpartum in dairy cows. Livestock Science 2009, 125(2/3):169-176.

37. Jaakson H, Ling K, Samarütel J, Ilves A, Kaart T, Kärt O, Ots M: Blood glucose and insulin repsonses during the glucose tolerance test in relation to dairy cows body condition and milk yield. Vet Med Zoot. 2013, T.62(84):28-35.

38. Kahn SE, Hull RL, Utzschneider KM: Mechanisms linking obesity to insulin resistance and type 2 diabetes. Nature 2006, 444:840-846.

39. Zachut M, Honig H, Striem S, Zick Y, Boura-Halfon S, Moallem U: Periparturient dairy cows do not exhibit hepatic insulin resistance, yet adipose-specific insulin resistance occurs in cows prone to high weight loss. J Dairy Sci 2013, 96(9):5656-5669.

40. Prodanović R., Korićanac G, Vujanac I, Djordjević A, Pantelić M, Romić S, Stanimirović Z, Kirovski D: Obesity-driven prepartal hepatic lipid accumulation in dairy cows is associated with increased CD36 and SREBP-1 expression. Research in veterinary science 2016, 107, 16-19.

\title{
ISPITIVANJE POVEZANOSTI IZMEĐU INDEKSA INSULINSKE REZISTENCIJE I METABOLIČKOG STATUSA KRAVA U RANOJ LAKTACIJI
}

\author{
CINCOVIĆ Marko, KIROVSKI Danijela, VUJANAC Ivan, BELIĆ Branislava, \\ DJOKOVIĆ Radojica
}

Insulinska rezistencija je fenomen koji prati metaboličku adaptaciju krava u ranoj laktaciji. Cilj ovog rada bio je da se ispita linearna povezanost između HOMA, QUICKI i RQUICKI indeksa insulinske rezistencije i metaboličkog statusa krava (koncentracije hormona, metabolita i telesne kondicije). U ogled je bilo uključeno 40 krava holštajnfrizijske rase u prvoj nedelji posle teljenja. Indeksi insulinske rezistencije imali su

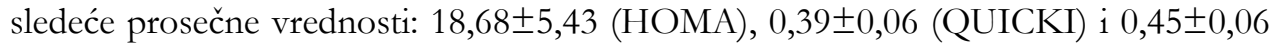
(RQUICKI). Ispitivanje linearne povezanosti izvršeno je testiranjem koeficijenta korelacije (r), determinacije $\left(\mathrm{r}^{2}, \%\right)$ i regresionog parametra beta (b) u linearnoj jednačini. HOMA indeks pokazuje negativnu korelaciju sa IGF-I ( $\mathrm{r}=-0,51, \mathrm{r}^{2}=25, \mathrm{~b}=-1,1257$, $\mathrm{p}<0,01)$ i pozitivnu korelaciju sa BHB $\left(r=0,48, r^{2}=23,2, b=0,0234, p<0,01\right)$. QUICKI indeks pozitivno korelira sa vrednostima IGF-I $\left(r=0,3, r^{2}=10,0 b=46,7900, p<0,05\right) i$ 
holesterola $\left(\mathrm{r}=0,44, \mathrm{r}^{2}=18,3, \mathrm{~b}=1,9021, \mathrm{p}<0,01\right)$, dok je negativna korelacija utvrđena sa BHB (r=0,51, $\left.\mathrm{r}^{2}=27,1, \mathrm{~b}=-1,7241, \mathrm{p}<0,01\right)$ i BCS $\left(\mathrm{r}=0,46, \mathrm{r}^{2}=20,91, \mathrm{~b}=-2,424\right.$, $\mathrm{p}<0,01)$. RQUICKI indeks pozitivno korelira sa IGF-I $\left(\mathrm{r}=0,48, \mathrm{r}^{2}=22,8, \mathrm{~b}=28,1230\right.$, $\mathrm{p}<0,01)$, T4 $\left(\mathrm{r}=0,47, \mathrm{r}^{2}=22,1, \mathrm{~b}=87,1420, \mathrm{p}<0,01\right)$ i trigliceridima $\left(\mathrm{r}=0,36, \mathrm{r}^{2}=13,0\right.$ $\mathrm{b}=0,0407, \mathrm{p}<0,05)$, a negatvno sa kortizolom $\left(\mathrm{r}=-0,36, \mathrm{r}^{2}=13,0 \mathrm{~b}=-9,0332, \mathrm{p}<0,05\right)$, STH $\left(r=-0,42, r^{2}=17,3, b=-5,4976, p<0,01\right)$, BHB $\left(r=-0,62, r^{2}=38,3, b=-1,1872\right.$, $\mathrm{p}<0,01)$, ukupnim bilirubinom $\left(\mathrm{r}=-0,58, \mathrm{r}^{2}=33,7, \mathrm{~b}=-7,1310, \mathrm{p}<0,01\right)$ i BCS $(\mathrm{r}=-0,6$, $\left.\mathrm{r}^{2}=36,4, \mathrm{~b}=-1,8347, \mathrm{p}<0,01\right)$. U zaključku, upotreba indeksa insulinske rezistencije može biti od koristi prilikom procene metaboličkog statusa krava u ranoj laktaciji. RQUICKI indeks je najprihvatljiviji prediktor metaboličkog statusa krava u ranoj laktaciji, s obzirom da pokauje linearnu povezanost sa više parametara povezanih sa procesom homeoreze. 